\title{
Mcl-1 downregulation by pro-inflammatory cytokines and palmitate is an early event contributing to $\beta$-cell apoptosis
}

\author{
F Allagnat ${ }^{1}$, D Cunha ${ }^{1}$, F Moore ${ }^{1}$, JM Vanderwinden ${ }^{2}$, DL Eizirik ${ }^{1}$ and AK Cardozo ${ }^{\star, 1}$
}

Pancreatic $\beta$-cell apoptosis is a key feature of diabetes mellitus and the mitochondrial pathway of apoptosis is a major mediator of $\beta$-cell death. We presently evaluated the role of the myeloid cell leukemia sequence 1 (Mcl-1), an antiapoptotic protein of the $\mathrm{Bcl}-2$ family, in $\beta$-cells following exposure to well-defined $\beta$-cell death effectors, for example, pro-inflammatory cytokines, palmitate and chemical endoplasmic reticulum (ER) stressors. All cytotoxic stresses rapidly and preferentially decreased Mcl-1 protein expression as compared with the late effect observed on the other antiapoptotic proteins, Bcl-2 and Bcl-xL. This was due to ER stress-mediated inhibition of translation through elF2 $\alpha$ phosphorylation for palmitate and ER stressors and through the combined action of translation inhibition and JNK activation for cytokines. Knocking down Mcl-1 using small interference RNAs increased apoptosis and caspase-3 cleavage induced by cytokines, palmitate or thapsigargin, whereas Mcl-1 overexpression partly prevented Bax translocation to the mitochondria, cytochrome $c$ release, caspase- 3 cleavage and apoptosis induced by the $\beta$-cell death effectors. Altogether, our data suggest that Mcl-1 downregulation is a crucial event leading to $\beta$-cell apoptosis and provide new insights into the mechanisms linking ER stress and the mitochondrial intrinsic pathway of apoptosis. Mcl-1 is therefore an attractive target for the design of new strategies in the treatment of diabetes.

Cell Death and Differentiation (2011) 18, 328-337; doi:10.1038/cdd.2010.105; published online 27 August 2010

Diabetes mellitus arises from the inability of the pancreatic $\beta$-cells to preserve metabolic homeostasis by the regulated secretion of insulin. The two main forms of diabetes are type 1 (T1D) and type 2 (T2D). ${ }^{1}$ T1D is primarily caused by an autoimmune attack leading to $\beta$-cell destruction and insulin deficiency. T2D is triggered by the combination of insulinoresistance and impaired $\beta$-cell function and survival, mostly secondary to metabolic factors through a process referred to as glucolipotoxicity. ${ }^{1}$ Both pathologies are characterized by decreased $\beta$-cell mass secondary to apoptosis; $\beta$-cell loss is more marked in T1D and is a relative late event in T2D, probably contributing to secondary failure of oral therapies. ${ }^{1}$ The mitochondrial intrinsic pathway of apoptosis controlled by the $\mathrm{B}$-cell lymphoma $2(\mathrm{Bcl}-2)$ protein family ${ }^{2}$ plays a major role in pancreatic $\beta$-cell death in both T1D and T2D. ${ }^{3}$

The Bcl-2 protein family can be divided into three groups, the antiapoptotic proteins (Bcl-2, B-cell lymphoma-extra large (Bcl-XL), Bcl-w, myeloid cell leukemia sequence 1 (Mcl-1) and $\mathrm{A} 1$ ), the multi-domain pro-apoptotic proteins (Bcl2-associated $\mathrm{X}$ protein (Bax), Bcl-2 homologous antagonist/killer (Bak) and Bok) and the pro-apoptotic $\mathrm{BH} 3-$ only proteins (including
Bim, Bid, neuronal death protein 5 (DP5, also known as Harakiri (Hrk)), Puma, Bad and Noxa). Upon death stimulus, Bax translocates from the cytosol to the mitochondria and oligomerizes with Bak, resulting in mitochondrial outer membrane permeabilization (MOMP). This allows proteins located in the mitochondrial intermembrane space, such as cytochrome $c$, to be released in the cytosol, in which they associate with cytosolic proteins to activate downstream executioner caspases resulting in apoptosis. ${ }^{4}$ The Bax/Bak activation is regulated by a delicate equilibrium between antiapoptotic Bcl-2 proteins and pro-apoptotic BH3-only proteins. Among the antiapoptotic proteins, overexpression of $\mathrm{Bcl}-2$ and $\mathrm{Bcl}-\mathrm{XL}$ have been shown to prevent $\beta$-cell apoptosis in a variety of models, ${ }^{5-7}$ but they may hamper $\beta$-cell function. ${ }^{7}$ The molecular role of $\mathrm{Mcl}-1$ in $\beta$-cells remains to be characterized. Mcl-1 is structurally unique among the $\mathrm{Bcl}-2$ family; it contains two PEST sequences (polypeptide sequences enriched in proline $(P)$, glutamic acid $(E)$, serine (S) and threonine (T)), which favor Mcl-1 degradation, thereby reducing its half-life. $\mathrm{Mcl}-1$ activity is also regulated by phosphorylation by the c-Jun $\mathrm{NH}$-terminal kinase (JNK)

\footnotetext{
${ }^{1}$ Laboratoire de Médecine Expérimentale, Université Libre de Bruxelles (ULB), Brussels, Belgium and ${ }^{2}$ Laboratoire de Neurophysiologie, Université Libre de Bruxelles (ULB), Brussels, Belgium

${ }^{*}$ Corresponding author: AK Cardozo, Laboratory of Experimental Medicine, Université Libre de Bruxelles (ULB), Route de Lennik, 808, CP 618, Brussels 1070, Belgium. Tel: + 322555 6306; Fax: + 322555 6239; E-mail: akupperc@ulb.ac.be

Keywords: Mcl-1; JNK; elF2 $\alpha$; apoptosis; pancreatic $\beta$-cells; diabetes

Abbreviations: Ad-Mcl-1, adenoviruses expressing the rat Mcl-1; Ad-LUC, adenoviruses expressing the luciferase protein; Bak, Bcl-2 homologous antagonist/killer; Bax, Bcl2-associated X protein; Bcl-2, B-cell lymphoma 2; Bcl-XL, B-cell lymphoma-extra large; BiP, binding immunoglobulin protein, also known as glucose-regulated protein 78 (Grp78); CHOP, C/EBP homologous protein; CPA, cyclopiazonic acid; DP5, neuronal death protein 5, also known as Harakiri (Hrk); elF2 $\alpha$, eukaryotic translation initiation factor 2 subunit alpha; ER, endoplasmic reticulum; FFA, free fatty acid; GSIS, glucose-stimulated insulin secretion; IL-1 $\beta$, interleukin 1 beta; IFN- $\gamma$, interferon gamma; JNK, c-Jun NH2-terminal kinase, also known as mitogen-activated protein kinase 8 (Mapk8); Mcl-1, myeloid cell leukemia sequence 1; MOMP, mitochondrial outer membrane permeabilization; PERK, PKR-like endoplasmic reticulum kinase; TNF- $\alpha$, tumor necrosis factor alpha; siRNA, small interference RNA Received 04.3.10; revised 21.6.10; accepted 23.7.10; Edited by G Nunez; published online 27.8.10
} 
and extracellular signal-regulated kinase (ERK) pathways in response to a variety of cell stimuli. ${ }^{8}$ This highly regulated state suggests that $\mathrm{Mcl}-1$, rather than other Bcl-2 pro-survival proteins, is an early pivotal protein in the regulation of cell survival in response to extracellular signals.

Pro-inflammatory cytokines (interleukin 1 beta (IL-1 $\beta$ ), tumor necrosis factor alpha (TNF- $\alpha$ ) and interferon gamma $($ IFN- $\gamma)$ ) and high concentrations of saturated free fatty acids (FFAs) such as palmitate are candidate mediators of beta cell apoptosis in T1D and T2D, respectively. ${ }^{1}$ In this study, we investigated the effect of cytokines, FFAs and chemical endoplasmic reticulum (ER) stressors on $\mathrm{Mcl}-1$ expression and, using both small interference RNA (siRNA) strategy and adenoviral-mediated $\mathrm{Mcl}-1$ overexpression, explored the role of $\mathrm{Mcl}-1$ in $\beta$-cell function and survival. The data obtained indicate that $\mathrm{Mcl}-1$ is a key antiapoptotic protein in $\beta$-cells, which is rapidly degraded in response to pro-apoptotic stimuli, leading to increased Bax translocation to the mitochondria, cytochrome $c$ release, cleavage of executioner caspase-3 and apoptosis in $\beta$-cells. These novel observations place $\mathrm{Mcl}-1$ as key determinant of $\beta$-cell fate during severe stress.

\section{Results}

Pro-inflammatory cytokines and palmitate decrease Mcl-1 expression in pancreatic $\boldsymbol{\beta}$-cells. To evaluate the effect of pro-inflammatory cytokines on Mcl-1 expression, INS-1E cells were treated for $24 \mathrm{~h}$ with IL-1 $\beta$, TNF- $\alpha$ and IFN- $\gamma$, alone or in combination, as indicated (Figure 1a). Western blot analysis revealed the presence of a doublet of $\mathrm{Mcl}-1$ isoforms around $40 / 42 \lambda \mathrm{kDa}$ as described previously. ${ }^{9}$ IL-1 $\beta$ alone decreased $\mathrm{Mcl}-1$ expression by $30 \%$. IFN- $\gamma$ and TNF- $\alpha$ had no effect individually, but induced a $40 \%$ decrease in Mcl-1 expression when combined. IFN- $\gamma$ also potentialized the effect of IL-1 $\beta$, leading to a $60 \%$ reduction of Mcl-1 expression (for quantification see Supplementary data; Supplementary Figure S1a). We have previously shown that cytokines induce ER stress in $\beta$-cells. ${ }^{10}$ To test whether ER stress contributes to $\mathrm{Mcl}-1$ decrease, INS-1E cells were exposed to the ER stressors thapsigargin, cyclopiazonic acid (CPA) and tunicamycin for $15 \mathrm{~h}$, resulting in a similar 40-60\% decrease in Mcl-1 expression (Figure $1 \mathrm{~b}$ and Supplementary Figure S1b). Salubrinal, a selective inhibitor of the cellular phosphatase complex that dephosphorylates the eukaryotic translation initiation factor 2 subunit alpha $(\mathrm{elF} 2 \alpha)^{11}$ also significantly decreased Mcl-1 expression, although by $25 \%$ only (Figure $1 \mathrm{~b}$ and Supplementary Figure S1b). INS-1E cells were also incubated for $15 \mathrm{~h}$ in the presence of the FFA oleate and the saturated FFA palmitate, the latter a known $\beta$-cell death effector. ${ }^{12,13}$ Palmitate, but not oleate, decreased Mcl-1 expression by $50 \%$ (Figure 1c and Supplementary Figure S1b). Similar to what we observed in INS-1E cells, Mcl-1 expression was decreased in primary rat islets treated for $48 \mathrm{~h}$ with TNF- $\alpha+$ IFN- $\gamma$ or IL $-1 \beta+$ IFN- $\gamma$, or for $24 \mathrm{~h}$ with thapsigargin, CPA or palmitate (Figure 1d). Time-course experiments of thapsigargin or IL-1 $\beta+\mathrm{IFN}-\gamma$ treatment indicated that $\mathrm{Mcl}-1$ protein expression is rapidly decreased (after 2 and $4 \mathrm{~h}$ of thapsigargin or $\mathrm{IL}-1 \beta+\mathrm{IFN}-\gamma$ treatment, respectively) as

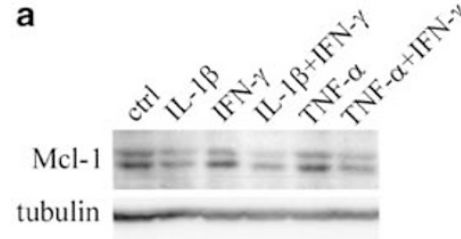

b

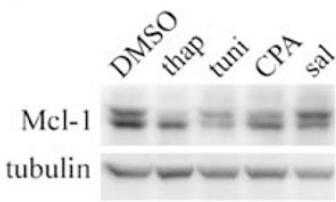

C

d

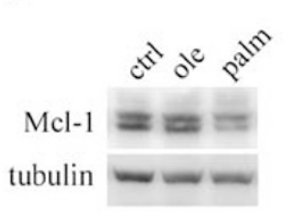

Mcl-1

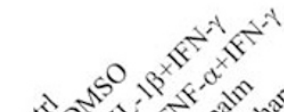

tubulin $=-\cdots-\cdots$

e

$\mathrm{IL}-1 \beta+\mathrm{IFN}-\gamma$

f

thap

$\begin{array}{llllll}0 & 2 & 4 & 8 & 16 & 24\end{array}$

$\begin{array}{lllll}0 & 2 & 4 & 8 & 16\end{array}$

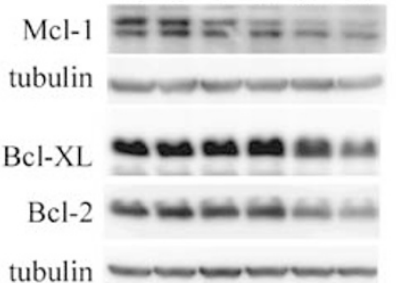

$\mathrm{Mcl}-1$

tubulin

$\mathrm{Bcl}-\mathrm{XL}$ a

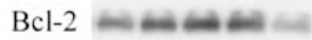

tubulin $\longrightarrow$

Figure $1 \mathrm{Mcl}-1$ protein expression is rapidly decreased upon $\beta$-cell exposure to pro-apoptotic agents. Mcl-1 protein expression was measured by western blot analyses in INS-1E cells and rat pancreatic islets treated with cytokines, chemical ER stressors or FFAs, as indicated. (a) INS-1E cells treated or not treated (ctrl) for $24 \mathrm{~h}$ with different cytokines (IL- $1 \beta$, TNF- $\alpha$ or IFN- $\gamma$, alone or in combination as indicated). (b) INS-1E cells treated for $15 \mathrm{~h}$ with DMSO (solvent for the ER stressors), thapsigargin (thap), tunicamycin (tuni), cyclopiazonic acid (CPA) or salubrinal (sal). (c) INS-1E cells exposed for $15 \mathrm{~h}$ to ctrl (control medium for FFAs) oleate (ole) or palmitate (palm). (d) Rat islets treated for $24 \mathrm{~h}$ with different cytokines (IL-1 $\beta$ or TNF- $\alpha$ in combination with IFN- $\gamma$ ), palmitate, thapsigargin or CPA. (e and f) Time-course experiments of INS-1E cells treated with IL- $1 \beta+\mathrm{IFN}-\gamma$ (e) or thapsigargin (f). All data are representative of at least four independent western blots

compared with the two other major antiapoptotic proteins, $\mathrm{Bcl}-2$ and $\mathrm{Bcl}-\mathrm{XL}$, whose expressions were decreased only after 15 and $24 \mathrm{~h}$ of treatment with thapsigargin or $\mathrm{IL}-1 \beta+\mathrm{IFN}-\gamma$, respectively (Figure $1 \mathrm{e}-\mathrm{f}$ ). On the other hand, Mcl-1 mRNA expression was upregulated by cytokines, thapsigargin and palmitate, indicating that the $\mathrm{Mcl}-1$ protein decrease is a post-transcriptional event (Figure 2a).

$\mathrm{Mcl}-1$ is constitutively targeted for degradation by the proteasome. ${ }^{8}$ INS-1E cells treated with the proteosomal inhibitor MG-132 displayed increased basal Mcl-1 expression and the inhibitor prevented IL-1 $\beta+$ IFN- $\gamma-$, TNF- $\alpha+$ IFN- $\gamma-$, thapsigargin- and palmitate-induced $\mathrm{Mcl}-1$ degradation (Figure $2 \mathrm{~b}$ and Supplementary Figure S1c), indicating that proteosomal degradation is involved in Mcl-1 downregulation. Cytokine-induced nitric oxide (NO) production is instrumental in cytokine-mediated ER stress and $\beta$-cell apoptosis, whereas palmitate and thapsigargin do not induce NO production in these cells. ${ }^{10,12}$ The NO synthase blocker NG-methyl-L-arginine (L-NMMA), which fully prevents cytokine-induced NO production in $\beta$-cells (data not shown; Cardozo et $a l^{10}$ ), had no effect on thapsigargin-mediated Mcl-1 decrease, whereas it completely prevented the 


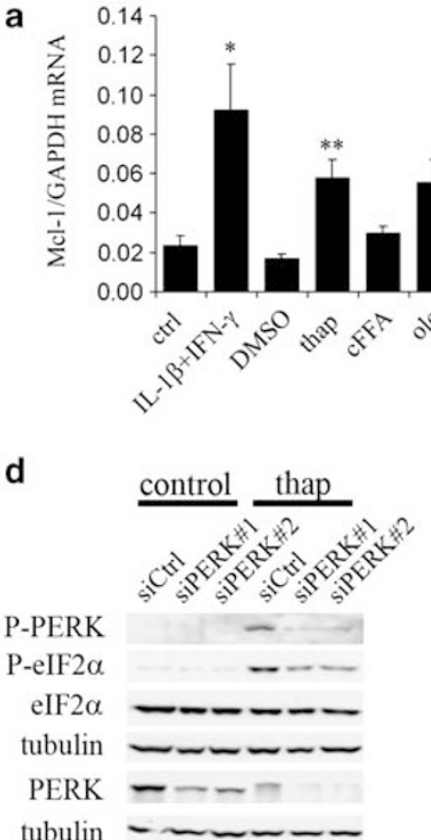

b

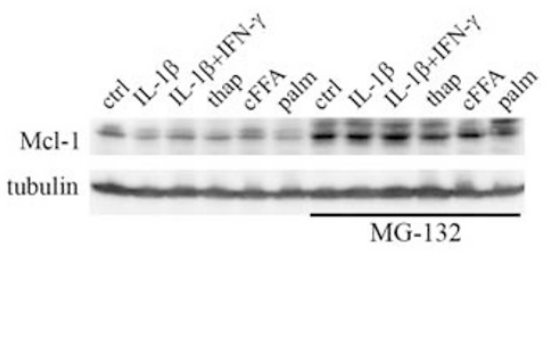

C

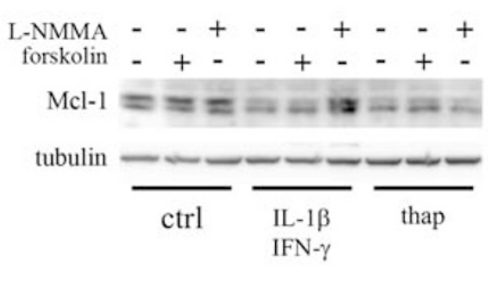

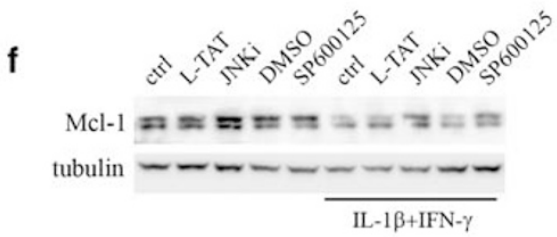

g

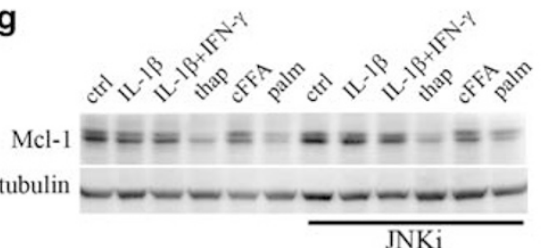

Figure 2 Regulation of Mcl-1 expression. (a) Real-time PCR analyses of Mcl-1 and GAPDH mRNA expression in response to IL-1 $\beta+$ IFN- $\gamma$, DMSO (solvent for the ER stressors), thapsigargin (thap), cFFA (control medium for FFAs, see Materials and Methods), oleate (ole) or palmitate (palm). ${ }^{*} P<0.05$, ${ }^{* *} P<0.01$ versus control (ctrl). (b) Mcl-1 protein expression was measured by western blot analysis in INS-1E cells exposed to cytokines (IL-1 $\beta$, in combination or not with IFN- $\gamma$ ), thapsigargin or palmitate, with or without the proteasome inhibitor MG-132. (c) Mcl-1 protein was measured by western blot analysis in INS-1E cells exposed to IL-1 $\beta+$ IFN- $\gamma$ or thapsigargin with or without L-NMMA or forskolin. (d) Western blot analysis of P-PERK, total PERK, P-elF2 $\alpha$ and elF2 $\alpha$ in INS-1E cells transfected with a control siRNA (siCtrl) or two PERK siRNA (siPERK nos. 1 or 2) and treated with thapsigargin. (e) Western blot analysis of Mcl-1 and P-elF2 $\alpha$ expression in INS-1E cells transfected with a control siRNA or the PERK siRNA no. 1 and treated with cytokines (IL-1 $\beta$, in combination or not with IFN- $\gamma$ ), thapsigargin or palmitate. (f) Western blot analysis of Mcl-1 in INS-1E cells treated or not treated (ctrl) for $8 \mathrm{~h}$ with cytokines (IL-1 $\beta+$ IFN- $\gamma$ ), in combination with the L-TAT peptide alone, the L-TAT-JNK inhibitory peptide (JNKi) or the chemical JNK inhibitor SP600125. (g) Western blot analysis of Mcl-1 in INS-1E cells exposed for $15 \mathrm{~h}$ to cytokines (IL-1 $\beta$, in combination or not with IFN- $\gamma$ ), thapsigargin or palmitate, together or not with the L-TAT-JNKi (JNKi). (b-g) Representative western blots of four independent experiments

cytokine effects on $\mathrm{Mcl}-1$ expression (Figure 2c). On the other hand, forskolin, an adenylate cyclase activator, which partially protects $\beta$-cells against cytokine- and palmitate-induced apoptosis, ${ }^{14,15}$ failed to prevent $\mathrm{Mcl}-1$ degradation (Figure 2c). INS-1E cells then were transfected with an siRNA targeting the PKR-like endoplasmic reticulum kinase (PERK), which is activated upon ER stress and phosphorylates the elongation factor elF $2 \alpha$, resulting in decreased protein synthesis. ${ }^{11}$ PERK knockdown using two different siRNAs decreased total PERK expression by $50 \%$ and nearly completely abolished thapsigargin-induced PERK phosphorylation (Figure $2 \mathrm{~d}$ ). This resulted in a $50 \%$ decrease in basal and stress-induced elF2 $\alpha$ phosphorylation (Figure $2 \mathrm{~d}$-e and Supplementary Figure S1d). PERK knockdown using siPERK no. 1 prevented thapsigargin-, palmitate- and IL-1 $\beta$-induced Mcl-1 downregulation (Figure 2e and Supplementary Figure S1d). However, it only partially reversed the inhibitory effects of the cytokine combinations (IL-1 $\beta+$ IFN- $\gamma$ and TNF- $\alpha+$ IFN$\gamma$ ) on Mcl-1 expression (Figure $2 \mathrm{e}$ and Supplementary Figure S1d). Similar observations were made using siPERK no. 2 (Supplementary Figure S1e).

JNK has been reported to inactivate Mcl- $1,{ }^{16}$ and cytokines induce a strong and rapid ( $1 \mathrm{~h}$ ) JNK phosphorylation in INS-1E cells, ${ }^{17,18}$ leading to a peak of C-Jun phosphorylation between
6 and $8 \mathrm{~h}$. We thus exposed INS-1E cells to IL- $1 \beta+\mathrm{IFN}-\gamma$ for $8 \mathrm{~h}$ in the presence of the JNK inhibitor peptide $(\mathrm{JNKi})^{19}$ or the chemical JNK inhibitor SP600125. ${ }^{18}$ Both inhibitors partially prevented the effect of cytokines on Mcl-1 expression, suggesting that JNK is involved in the cytokine-induced $\mathrm{Mcl}-1$ downregulation (Figure 2f). Western blot analysis of c-Jun phosphorylation confirmed the efficiency of the inhibitors in blocking JNK activity (Supplementary Figure S1f). ER stress has been shown to induce a late JNK activation in $\beta$ cells $;{ }^{10}$ however, the JNKi peptide did not prevent the effects of a $15 \mathrm{~h}$ exposure to thapsigargin or palmitate on $\mathrm{Mcl}-1$ downregulation. At this time point, JNK inhibition fully prevented the Mcl-1 downregulation induced by IL-1 $\beta$ alone or TNF- $\alpha+\mathrm{IFN}-\gamma$, and partially prevented the effect of $\mathrm{IL}-1 \beta+\mathrm{IFN}-\gamma$ (Figure $2 \mathrm{~g}$ and Supplementary Figure S1c). These data indicate that palmitate and thapsigargin downregulate $\mathrm{Mcl}-1$ protein through $\mathrm{ER}$ stress-mediated inhibition of translation, whereas cytokines decrease Mcl-1 through the combined action of translation inhibition and JNK activation.

In other cell types, Mcl-1 stability has been shown to be modulated through phosphorylation by the ERK 1,2 and the glycogen synthase kinase-3 $\beta$ (GSK-3 $\beta){ }^{8}$ IL- $1 \beta+\mathrm{IFN}-\gamma$ but not TNF- $\alpha+$ IFN $-\gamma$ stimulate ERK phosphorylation in INS-1E 
cells. ${ }^{20,21}$ The peak of IL-1 $\beta+$ IFN- $\gamma$-induced ERK activation occurs after $4-8 \mathrm{~h}$ of treatment, which is concomitant with Mcl-1 downregulation. However, blocking IL-1 $\beta+\mathrm{IFN}-\gamma$-induced ERK activity using PD98059 had no effect of Mcl-1 downregulation after $8 \mathrm{~h}$ exposure to IL-1 $\beta+\mathrm{IFN}-\gamma$ (Supplementary Figure S2a). Time-course experiments indicated that INS-1E cells have a high basal GSK- $3 \alpha, \beta$ phosphorylation, suggesting a low GSK- $3 \alpha, \beta$ activity since the phosphorylated form is inactive (Supplementary Figure S2b). IL- $1 \beta+$ IFN- $\gamma$ further stimulated GSK- $3 \alpha, \beta$ phosphorylation after $8 \mathrm{~h}$, and the levels of phospho (P)- and total GSK-3 $\beta$ were decreased at later time points (16 and $24 \mathrm{~h}$ ). TNF- $\alpha+\mathrm{IFN}-\gamma$ had no significant effect on P-GSK-3 $\alpha, \beta$ and total GSK-3 $\beta$ (Supplementary Figure S2c). We next analyzed $\mathrm{Mcl}-1$ protein expression in the presence of two specific GSK-3 $\beta$ inhibitors (SB216763 and bromoindirubin-3'-oxime $(\mathrm{BIO}))^{22,23}$ in INS-1E cells treated or not treated for $8 \mathrm{~h}$ with IL-1 $\beta+\mathrm{IFN}-\gamma$. As a control for the effects of the compounds on GSK-3 activity, we evaluated $\beta$-catenin protein expression; $\beta$-catenin is targeted for proteosomal degradation upon phosphorylation by GSK-3. ${ }^{22}$ Both SB216763 and BIO increased beta-catenin expression in INS-1E cells, indicating that these compounds efficiently inhibit GSK-3 activity (Supplementary Figure S2d). On the other hand, the two inhibitors had no effect on Mcl-1 expression, indicating that GSK-3-mediated Mcl-1 phosphorylation is not involved in $\mathrm{Mcl}-1$ downregulation in INS-1E cells.

Mcl-1 knockdown increases $\beta$-cell apoptosis. To elucidate the role of $\mathrm{Mcl}-1$ in $\beta$-cells, INS-1E cells were transfected with two siRNAs targeting the rat $\mathrm{Mcl}-1$. Both siRNAs efficiently decreased Mcl-1 expression (Figure 3a). We then studied the effect of $\mathrm{Mcl}-1$ knockdown on $\beta$-cell survival. Transfection with Mcl-1 siRNA no. 1 (Figure $3 \mathrm{~b}$ and Supplementary Figure S3a) or no. 2 (Supplementary Figure S2b) significantly increased basal and induced apoptosis in all conditions and at all time points studied in INS-1E cells. Similar data were obtained in fluorescence-activated cell sorting (FACS)-purified primary $\beta$-cells using Mcl-1 siRNA no. 1 (Figure $3 c$ and Supplementary Figure S3c).

Western blot analysis revealed that knocking down Mcl-1 increased caspase-3 cleavage in control, cytokine-, thapsigargin- or palmitate-treated cells (Figure 4). It is noteworthy that $\mathrm{Mcl}-1$ knockdown did not affect $\mathrm{Bcl}-2$ or $\mathrm{Bcl}-\mathrm{XL}$ expression, and did not modify the effects of cytokines, thapsigargin or palmitate on the expression of the ER stress markers: binding immunoglobulin protein (BiP; also known as glucose regulated protein 78 (Grp78)), C/EBP homologous protein (CHOP) (Figure 4) and XBP-1s (data not shown).

Mcl-1 overexpression prevents $\beta$-cell apoptosis. We next evaluated whether $\mathrm{Mcl}-1$ overexpression increases $\beta$-cell viability following exposure to different stressful agents. For this purpose, an adenovirus overexpressing rat Mcl-1 (Ad-Mcl-1) was generated. As compared with noninfected (NI) cells or cells infected with the control virus encoding luciferase (Ad-LUC), INS-1E cells infected with the virus encoding $\mathrm{Mcl}-1$ (Ad-Mcl-1) at multiplicity of infections 2 , 5 and 10 displayed dose dependently increased levels of Mcl-1 (Figure 5a). Western blot analysis of mitochondrial

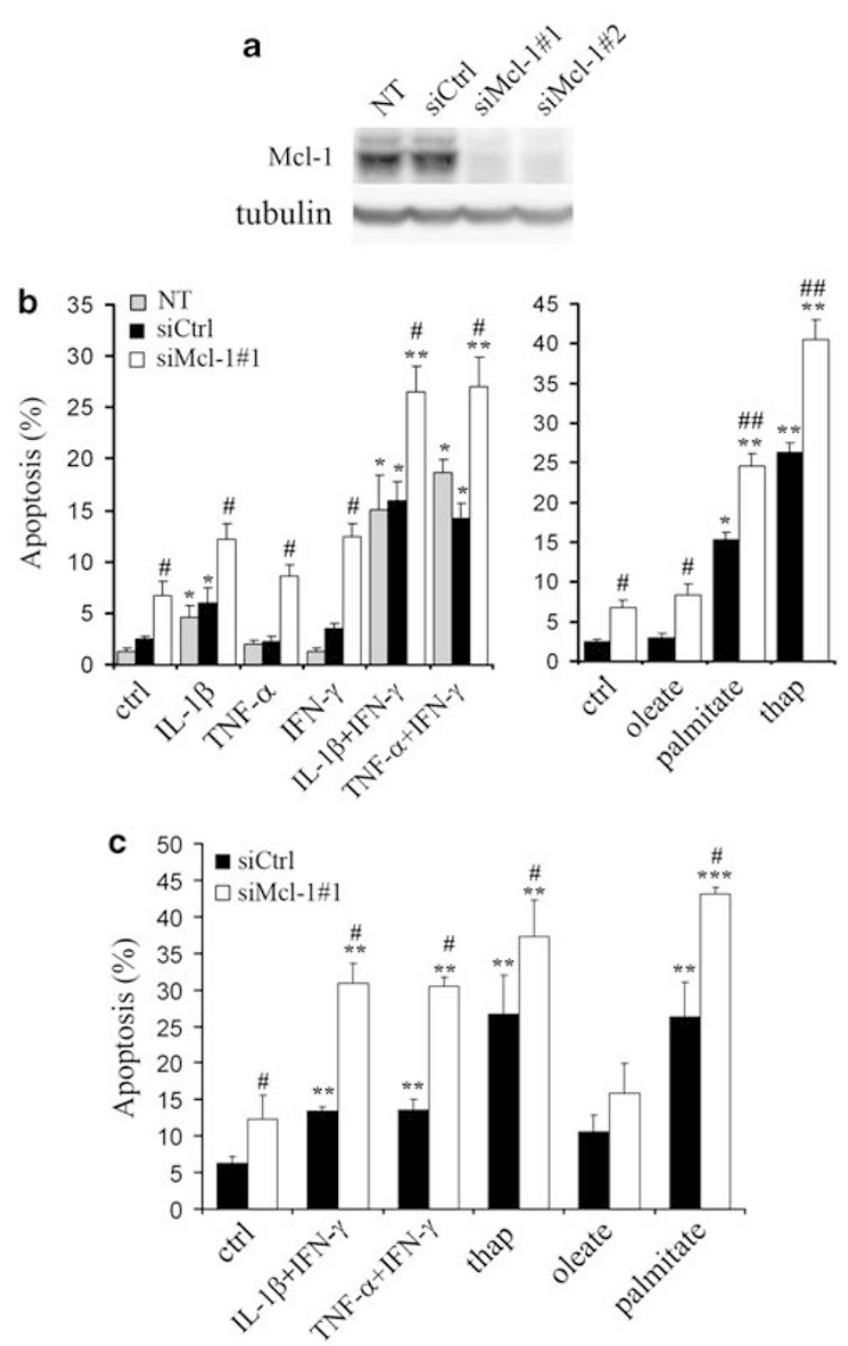

Figure $3 \mathrm{Mcl}-1$ knockdown increases $\beta$-cell apoptosis. (a) Representative western blot analysis of five independent experiments showing Mcl-1 expression in INS-1E transfected with a control siRNA (siCtrl) or two different Mcl-1 siRNAs (siMcl-1 nos. 1 and 2). (b) INS-1E cells were not transfected (gray bars) or transfected with siCtrl (black bars) or siMcl-1 no. 1 (white bars) and treated; left panel: for $24 \mathrm{~h}$ with cytokines (IL-1 $\beta$, TNF- $\alpha$ or IFN- $\gamma$, alone or in combination as indicated); right panel: for $15 \mathrm{~h}$ with thapsigargin (thap) or FFAs (oleate or palmitate). (c) FACS-purified primary $\beta$-cells were transfected with the siCtrl (black bars) or siMcl-1 no. 1 (white bars) and treated for $24 \mathrm{~h}$ with cytokines, thapsigargin, oleate or palmitate, as indicated. (b and $\mathbf{c}$ ) Prevalence of apoptosis was evaluated by HO-propidium iodide staining. Data are mean \pm S.E.M. of at least four independent experiments, expressed as the percentage of apoptotic cells over the total number of cells counted. ${ }^{*} P<0.05,{ }^{* \star} P<0.01,{ }^{* * *} P<0.001$ versus respective non-treated condition. ${ }^{\#} P<0.05,{ }^{\# \#} P<0.01$ versus respective siCtrl-transfected condition

and cytosolic fractions extracted from INS-1E cells infected with Ad-LUC or Ad-Mcl-1 revealed that the exogenous Mcl-1 is mostly localized in the mitochondrial fraction. The endogenous $\mathrm{Mcl}-1$ protein was also located in the mitochondrial fraction and absent from the cytosolic fraction. As previously described in other cell types, ${ }^{2}$ Bak colocalized with the mitochondrial marker CoxIV, whereas Bax was located in the cytosol (Figure 5b). Interestingly, $\mathrm{Bcl}-2$ and $\mathrm{Bcl}-\mathrm{XL}$ were present in both cytosolic and mitochondrial fractions, in line with previous reports that $\mathrm{Bcl}-2$ and $\mathrm{Bcl}-\mathrm{XL}$ have a broader 

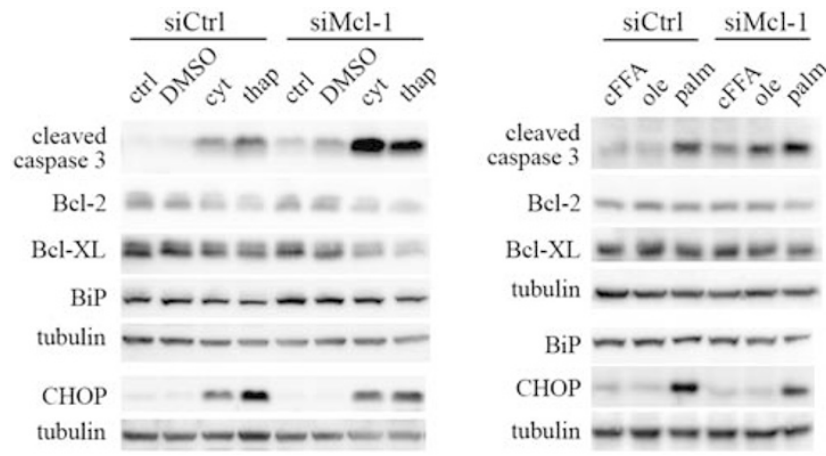

Figure 4 Mcl-1 knockdown increases caspase-3 cleavage. INS-1E cells were transfected with a control siRNA (siCtrl) or the rat Mcl-1 siRNA no. 1 (siMcl-1) and treated or not treated (ctrl) for $15 \mathrm{~h}$ with IL- $1 \beta+\mathrm{IFN}-\gamma$ (cyt), DMSO (see Materials and methods), thapsigargin (thap), cFFA (control for FFAs, see Materials and methods), oleate (ole) or palmitate (palm). Data are representative of four independent western blot experiments

cellular distribution as compared with $\mathrm{Mcl}-1 .{ }^{9}$ We next evaluated the effect of $\mathrm{Mcl}-1$ overexpression on $\beta$-cell survival. As compared with $\mathrm{NI}$ or Ad-LUC-infected cells, Ad-Mcl-1-infected INS-1E cells displayed a $50 \%$ reduction in apoptosis following exposure to IL- $1 \beta+\mathrm{IFN}-\gamma$, TNF- $\alpha+$ IFN- $\gamma$, thapsigargin, tunicamycin or palmitate (Figure $5 \mathrm{c}$ ). Similar results were obtained in FACS-purified primary $\beta$-cells after treatment with $\mathrm{IL}-1 \beta+\mathrm{IFN}-\gamma$, thapsigargin or palmitate (Figure $5 \mathrm{~d}$ ). Time-course experiments revealed that the protection was continuous from 8 to $48 \mathrm{~h}$ treatment with IL-1 $\beta+$ IFN- $\gamma$ (Supplementary Figure S3a). Mcl-1 overexpression also reduced by $50 \%$ the caspase-3 cleavage induced by IL-1 $\beta+\mathrm{IFN}-\gamma$ (Figure 6a), thapsigargin (Figure 6b) or palmitate (Figure 6c), confirming the antiapoptotic action of Mcl-1. Similar to Mcl-1 knockdown, Mcl-1 overexpression had no impact on Bax, Bak, Bcl-2, Bcl-XL, $\mathrm{CHOP}$ and BiP expression (Figure 6).

Mcl-1 overexpression prevents Bax translocation to the mitochondria. Mcl-1 has been shown to modulate Bax/Bakmediated MOMP, release of cytochrome $c$ and apoptosis. ${ }^{24}$ We studied Bax and cytochrome $c$ localization by immunostaining in INS-1E cells overexpressing Mcl-1 and exposed to IL-1 $\beta+\mathrm{IFN}-\gamma$. Upon apoptosis (determined by nucleus morphology using DNA labeling by Hoechst (HO)), INS-1E cells displayed a diffuse cytosolic cytochrome $c$ staining, whereas it was discrete and typically mitochondrial in living cells, colocalizing with the mitochondrial marker apoptosisinducible factor (AIF) (Figure 7a). The mitochondrial morphology, monitored using AIF (Figure 7a) or ATP synthase (Figure $7 \mathrm{~b}$ ), changed drastically between live and apoptotic cells, the latter showing disintegration of the tubular mitochondrial network and formation of punctiform, fragmented mitochondria. In contrast with the cytochrome $c$ staining, the Bax labeling changed from a homogeneous cytosolic staining in live cells to a discrete punctate staining that colocalized with the mitochondrial marker ATP synthase in apoptotic cells (Figure 7b). Quantitative assessment revealed that $\mathrm{Mcl}-1$ overexpression reduced by $70 \%$ Bax translocation and cytochrome $c$ release induced by IL- $1 \beta+\mathrm{IFN}-\gamma$ (Figure 7c),

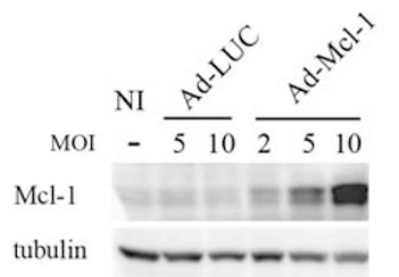

b

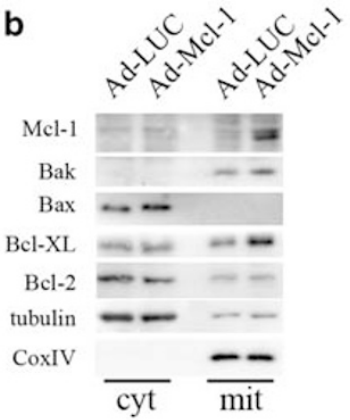

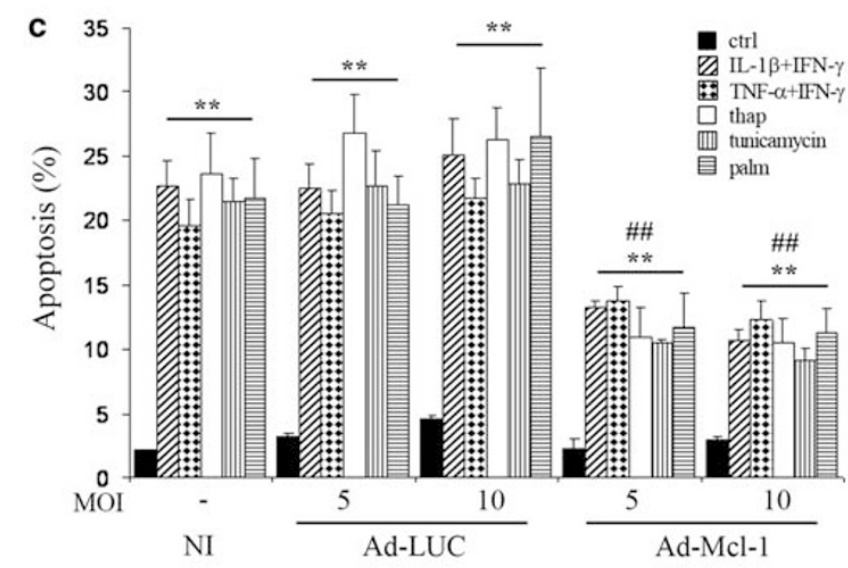

d

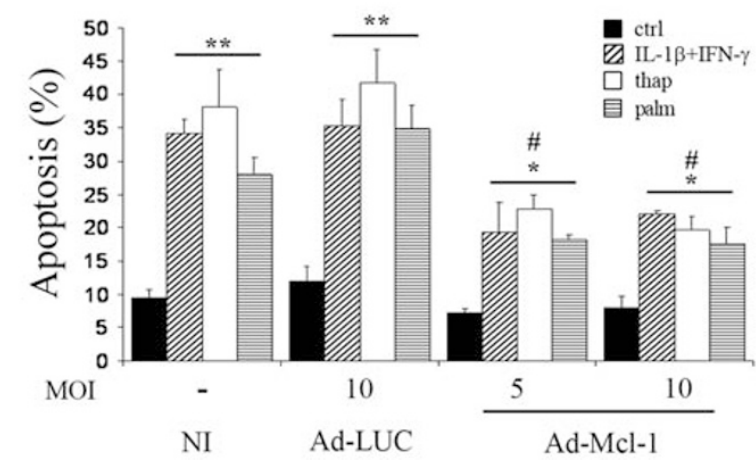

Figure $5 \mathrm{Mcl}-1$ overexpression prevents $\beta$-cell apoptosis. INS-1E- $(\mathbf{a}-\mathbf{c})$ or FACS-purified primary $\beta$-cells (d) were infected or not infected (NI) with adenoviruses encoding luciferase (Ad-LUC) or Mcl-1 (Ad-Mcl-1) at different multiplicity of infection (MOI), as indicated. (a) Representative western blot analysis of four independent experiments showing expression of Mcl-1 and tubulin in total INS-1E protein extracts. (b) Representative western blot analysis of four independent experiments showing the expression of $\mathrm{Mcl}-1, \mathrm{Bcl}-2, \mathrm{Bcl}-\mathrm{XL}, \mathrm{Bax}$ Bak, tubulin and CoxIV in cytosolic and mitochondrial protein fractions. (c) INS-1E cells were infected or $\mathrm{NI}$ with Ad-LUC or Ad-Mcl-1, and then treated or not treated (ctrl; black) for $15 \mathrm{~h}$ with IL- $1 \beta+$ IFN- $\gamma$ (striped), TNF- $\alpha+$ IFN- $\gamma$ (tiled), thapsigargin (white), tunicamycin (vertical stripes) or palmitate (horizontal stripes). (d) FACS purified primary $\beta$-cells were infected or $\mathrm{NI}$ with Ad-LUC or Ad-Mcl-1, and then treated or not treated (black bars) for $24 \mathrm{~h}$ with IL-1 $\beta+\mathrm{IFN}-\gamma$ (striped bars), thapsigargin (white bars) or palmitate (horizontal stripes). (c and $\mathbf{d})$ Apoptosis was evaluated by HO-propidium iodide staining. Data are mean \pm S.E.M. of at least four independent experiments, expressed as the percentage of apoptotic cells over the total number of cells counted. ${ }^{*} P<0.05,{ }^{* *} P<0.01$ versus respective non-treated condition. ${ }^{\#} P<0.05,{ }^{\# \#} P<0.01$ versus respective $\mathrm{NI}$ condition

as compared with Ad-LUC-infected cells. Similar data were obtained after a $15 \mathrm{~h}$ exposure to thapsigargin (Supplementary data, Supplementary Figure S4) or palmitate 
a

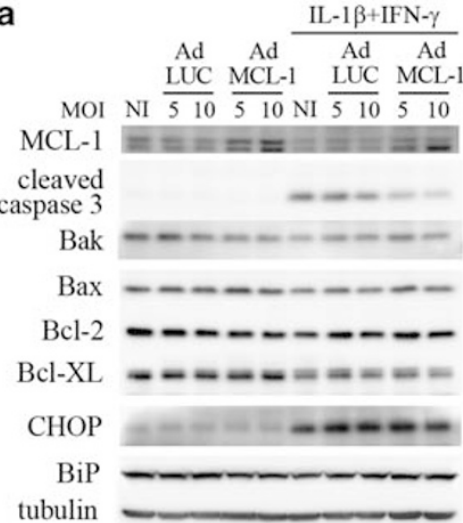

b

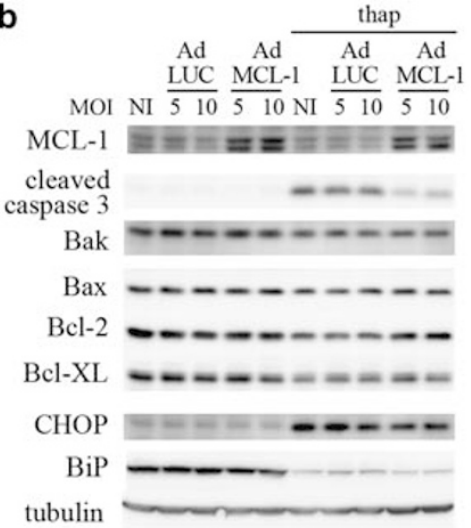

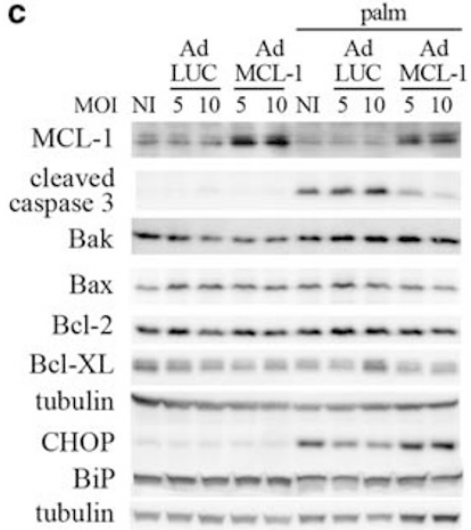

Figure 6 Mcl-1 overexpression prevents caspase-3 cleavage. INS-1E cells were infected or not infected (NI) with adenoviruses encoding luciferase (Ad-LUC) or Mcl-1 (Ad-Mcl-1) and treated or not treated for $15 \mathrm{~h}$ with IL-1 $\beta+$ IFN- $\gamma(\mathbf{a})$, thapsigargin (b) or palmitate (c). Data are representative western blots of three to five independent experiments

(Supplementary Figure S5), suggesting that $\mathrm{Mcl}-1$ protects $\beta$-cells from different pro-apoptotic stimuli by preventing Bax translocation and subsequent cytochrome $c$ release (Figure 8).

Acute and short-term changes in Mcl-1 expression do not affect $\beta$-cell function or proliferation. Bcl-XL overexpression has been shown to inhibit glucose-induced insulin secretion. ${ }^{7}$ In contrast, neither Mcl-1 knockdown (Supplementary Figure S6a) nor overexpression (Supplementary Figure S6b) altered the basal or glucose-stimulated insulin secretion (GSIS). Mcl-1 overexpression did not prevent the GSIS inhibition induced by a $15 \mathrm{~h}$ treatment with IL-1 $\beta+$ IFN- $\gamma$ (Supplementary Figure S6c).

Mcl- 1 transgenic mice have increased $\beta$-cell mass. ${ }^{25}$ Under the present experimental conditions, however, a 48-h period of $\mathrm{Mcl}-1$ overexpression did not modify INS-1E cells proliferation, as measured by BrDU incorporation (Supplementary data, Supplementary Figure S7).

\section{Discussion}

The aim of this study was to elucidate the role of the Bcl-2 protein family member $\mathrm{Mcl}-1$ in $\beta$-cell function and survival. Knocking down $\mathrm{Mcl}-1$ sensitized $\beta$-cells to apoptosis, whereas overexpressing it protected these cells against pathophysiologically relevant agents (pro-inflammatory cytokines or palmitate), as well as chemical ER stressors, showing that $\mathrm{Mcl}-1$ has an important antiapoptotic role in $\beta$-cells. Interestingly, $\mathrm{Mcl}-1$ was rapidly degraded by cytokines, palmitate and chemical ER stressors, as compared with the other antiapoptotic proteins $\mathrm{Bcl}-2$ and $\mathrm{Bcl}-\mathrm{XL}$, setting Mcl-1 decrease as a precursor event in $\beta$-cell apoptosis. $\mathrm{Mcl}-1$ downregulation was not a transcriptional event, but was secondary to ER stress-mediated inhibition of translation for palmitate and ER stressors, and to the combined action of translation inhibition and JNK activation for cytokines. Altogether, these novel observations strongly suggest that $\mathrm{Mcl}-1$ degradation may be a decisive step leading to $\beta$-cell apoptosis in T1D and T2D.
Mcl-1 is a very labile protein with a $30-90$ min half-life and inhibition of de novo Mcl-1 synthesis results in rapid $\mathrm{Mcl}-1$ downregulation. ${ }^{8}$ In this study, we confirm our previous findings that palmitate ${ }^{13,26}$ and cytokines $^{10}$ induce the PERK-elF $2 \alpha$ pathway in $\beta$-cells, leading to decreased protein translation. ${ }^{11}$ We presently show, using salubrinal, that phosphorylation of elF2 $\alpha$ is sufficient to significantly reduce Mcl-1 protein level. Knocking down PERK confirmed that elF2 $\alpha$ phosphorylation is instrumental in palmitate- and thapsigargin-induced $\mathrm{Mcl}-1$ downregulation. This is in line with previous reports of elF2 $\alpha$-dependent Mcl- 1 downregulation in other cell types. ${ }^{27,28}$ The effect of cytokines is, however, more complex as blocking elF2 $\alpha$ phosphorylation only partly prevents cytokine-induced $\mathrm{Mcl}-1$ downregulation. $\mathrm{Mcl}-1$ stability in other cell types is influenced through phosphorylation of various residues by multiple kinases, including JNK, ERK and GSK-3 $\beta .^{8}$ Cytokines induce JNK in $\beta$-cells ${ }^{18,29}$ and phosphorylation of $\mathrm{Mcl}-1$ by JNK facilitates $\mathrm{Mcl}-1$ degradation in HEK293 cells. $^{16}$ We presently observed that JNK contributes to cytokine-mediated $\mathrm{Mcl}-1$ downregulation. Cytokine-induced JNK phosphorylation is a rapid and transitory event (peak at $1 \mathrm{~h}$ ), probably contributing to the early Mcl-1 degradation (4-8 h). The role of JNK, however, is partial and restricted to cytokines (blocking JNK did not prevent palmitate- or thapsigargin-induced Mcl-1 degradation), indicating that translation arrest is the main event leading to $\mathrm{Mcl}-1$ downregulation. ERK-mediated phosphorylation has been proposed to stabilize $\mathrm{Mcl}-1$ and we previously showed that IL-1 $\beta+\mathrm{IFN}-\gamma$ induce ERK in $\beta$-cells. ${ }^{20,21}$ However, blocking ERK activity had no effect on $\mathrm{Mcl}-1$ expression, suggesting that ERK activation is not a major player in cytokine-induced changes in Mcl-1 expression in $\beta$-cells. This is in accordance with previous studies showing that ERK plays a minor role in $\mathrm{Mcl}-1$ regulation in other models. ${ }^{16,30}$ GSK-3 has also been shown to phosphorylate $\mathrm{Mcl}-1$, thereby facilitating its degradation; ${ }^{31}$ however, our present data suggest that INS-1E cells have low GSK-3 $\beta$ activity, and that the kinase is not involved in $\mathrm{Mcl}-1$ regulation.

Altogether, our data show that palmitate and thapsigargin decrease $\mathrm{Mcl}-1$ expression by ER stress-dependent inhibition 
a

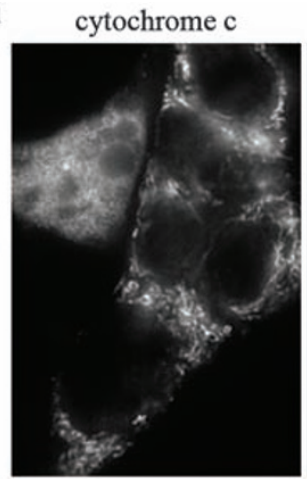

b
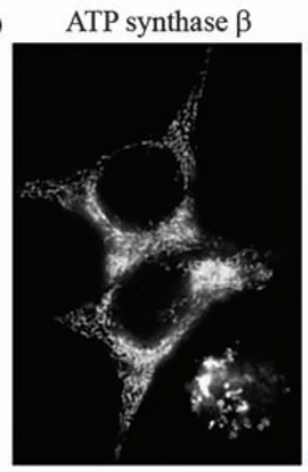

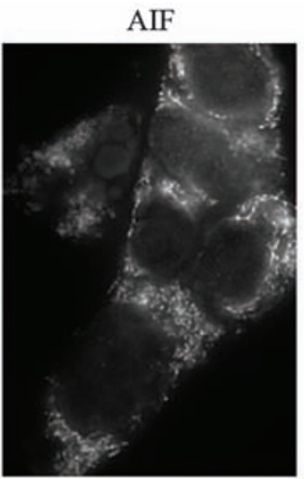

$\operatorname{Bax}$

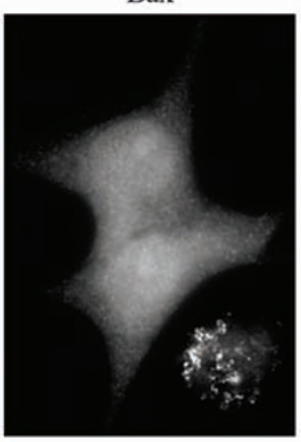

Hoescht

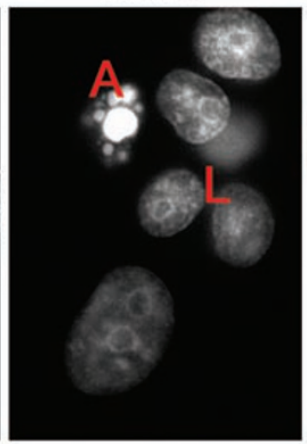

Hoescht

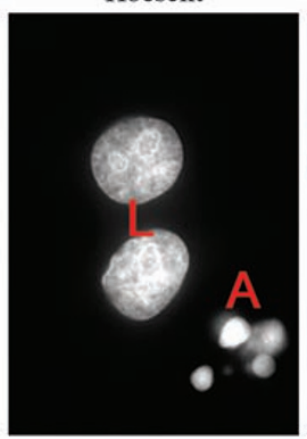

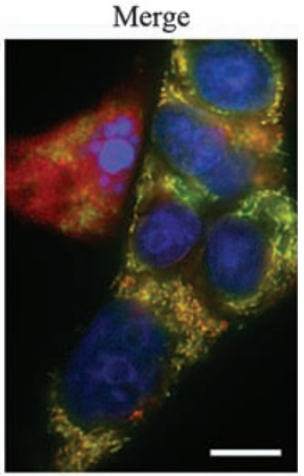

Merge

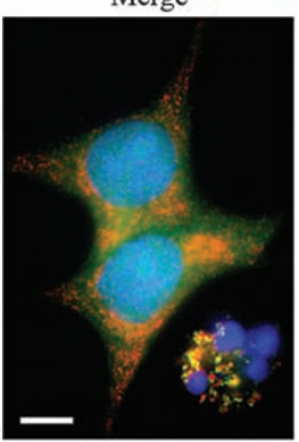

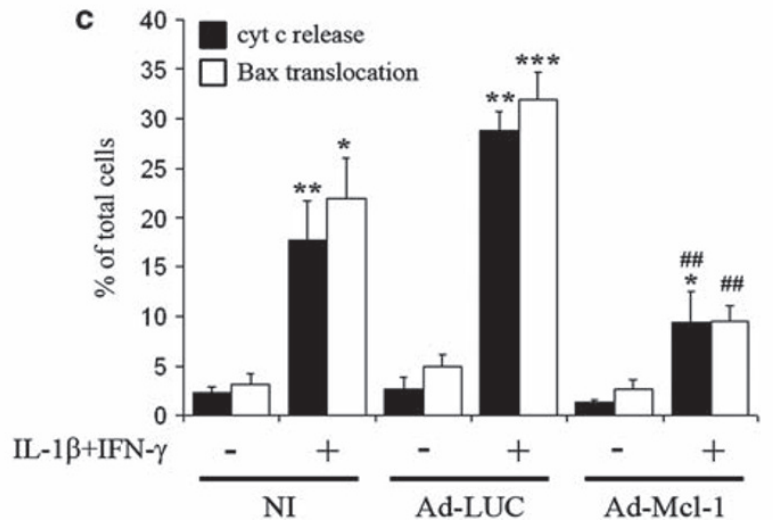

Figure $7 \mathrm{Mcl}-1$ overexpression prevents Bax translocation to the mitochondria and cytochrome $c$ release. INS-1E cells were infected or not (NI) with adenoviruses encoding luciferase (Ad-LUC) or Mcl-1 (Ad-Mcl-1) at an MOI 5 and treated with IL-1 $\beta+\mathrm{IFN}-\gamma$ for $24 \mathrm{~h}$. At 5 days after infection, cells were fixed and analyzed by immunofluorescence. (a) Representative field showing live (L) and apoptotic cells $(A)$ stained using anti-cytochrome $c$, anti-AIF, the DNA labeling chemical $H O$ and a merge picture of all channels (red, cyt $c$; green, AIF; blue, HO). (b) Representative field showing $L$ and A cells stained using anti-ATP synthase $\beta$, anti-Bax, HO and a merged picture of all channels (red, ATPsynth; green, Bax; blue, HO). (a and b) Magnification, $\times 100$; the scale bar represents $10 \mu \mathrm{m}$. (c) Data are mean \pm S.E.M. of four independent experiments, expressed as the percentage of cells showing Bax translocation and/or cytochrome $c$ release over the total number of cells counted. ${ }^{*} P<0.05,{ }^{* *} P<0.01$, ${ }^{* * *} P<0.001$ versus respective non-treated control. ${ }^{\# \#} P<0.01$ versus respective $\mathrm{Nl}$ condition

of translation, whereas cytokines induce Mcl-1 downregulation by a combination of decreased translation and increased JNK activity (Figure 8).

Increasing evidence support the involvement of $\mathrm{Bcl} 2$ family members in $\beta$-cell apoptosis in response to pro-inflammatory cytokines, saturated FFA and ER stress. ${ }^{3,5-7,13,18,32}$ Here, we show that cytokines, palmitate and thapsigargin, induce Bax translocation, cytochrome $c$ release and caspase-3 cleavage, independently of changes in Bcl-2, Bcl-XL, Bax and Bak expression levels, but partly as a consequence of $\mathrm{Mcl}-1$ downregulation (Figure 8). Our data are in agreement with previous studies showing that Mcl-1, in spite of its preferential mitochondrial localization, ${ }^{33}$ is able to prevent Bax activation and translocation. ${ }^{24}$ The fact that Mcl-1 is unlikely to interact directly with $\mathrm{Bax}^{33}$ suggests that additional factors are involved in the inhibitory action of $\mathrm{Mcl}-1$ on Bax translocation. Truncated Bid (tBid) is one of the factors contributing to Bax translocation to the mitochondria, ${ }^{34}$ and has been shown to be involved in cytokine-induced $\beta$-cell apoptosis. ${ }^{35} \mathrm{Mcl}-1$ has been proposed to act by sequestering tBid, thereby blocking Bax translocation and cytochrome $c$ release. ${ }^{36}$ Further studies remain to be performed to 


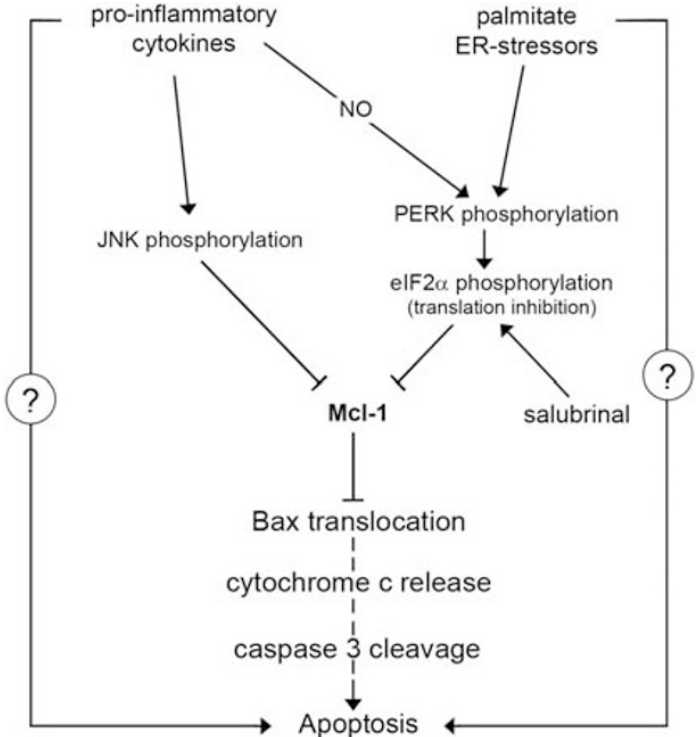

Figure 8 Scheme depicting the central role of $\mathrm{Mcl}-1$ in apoptosis induced by cytokines, palmitate and ER stressors. Palmitate and chemical ER stressors (thapsigargin) induce PERK phosphorylation, which phosphorylates elF2 $\alpha$, leading to decreased translation, and hence reduced Mcl-1 synthesis. Pro-inflammatory cytokines induce both phosphorylation of elF2 $\alpha$ and JNK activation, leading to decreased Mcl-1 translation and increased $\mathrm{Mcl}-1$ degradation, respectively. The decrease in Mcl-1 protein level permits the translocation of Bax to the mitochondria, in which it oligomerizes with Bak to form a channel leading to mitochondrial outer membrane permeabilization (MOMP), release of cytochrome $c$, cleavage of effector caspases, including caspase-3, and apoptosis

determine whether $\mathrm{Mcl}-1$ overexpression results in tBid sequestration, and whether this contributes to the blockade of Bax translocation. In vitro studies suggest that $\mathrm{Mcl}-1$ may interact with other $\mathrm{BH} 3-o n l y$ proteins including Puma, Noxa, Bim and DP $5,{ }^{37}$ suggesting that additional proteins involved in Bax translocation might be sequestered by $\mathrm{Mcl}-1$. In line with this hypothesis, we recently showed that the pro-apoptotic $\mathrm{BH} 3-$ only proteins DP5/Hrk and PUMA, which are rapidly overexpressed in response to ER stress and cytokines in $\beta$-cells, are involved in $\beta$-cell apoptosis. ${ }^{18,32}$ Taken together, these data suggest that, at least in the case of cytokines, proteins of the $\mathrm{Bcl}-2$ family are regulated at several levels in $\beta$-cells; while $\mathrm{Mcl}-1$ is degraded, $\mathrm{BH} 3$-only proteins (tBid, DP5, PUMA, etc.) are activated, thereby tipping the pro-/antiapoptotic balance toward apoptosis. Alternatively, other pro-apoptotic mechanisms involving additional $\mathrm{Bcl}-2$ family members (Bim, NOXA, etc.) and/or other pathways (XIAP, FLIPs, etc.) may contribute to $\beta$-cell apoptosis.

Many reports suggest that ER stress plays a major role in palmitate-induced $\beta$-cell apoptosis. ${ }^{12,13,26,38}$ The present data support this hypothesis and provide new insights into the mechanism linking palmitate, ER stress and the intrinsic pathway of apoptosis through elF $2 \alpha$ phosphorylation and $\mathrm{Mcl}-1$ degradation. On the other hand, the role of ER stress in cytokine-induced $\beta$-cell apoptosis remains controversial. ${ }^{10,38-40}$ We presently show that the cytokine effects on $\mathrm{Mcl}-1$ require $\mathrm{ER}$ stress-dependent and -independent mechanisms (JNK activation), suggesting that cytokines may, depending on the severity and duration of exposure, induce apoptosis by ER stress-dependent and -independent mechanisms. This may account for the contradictory findings in this field. ${ }^{10,38-40}$ Altogether, our data point out Mcl-1 degradation, whether it is due to ER stress or JNK activation, as a novel and common mechanism for $\beta$-cell apoptosis triggered by potential death effectors involved in the onset of T1D and T2D (Figure 8).

New strategies to prevent the development of diabetes require improving $\beta$-cell survival without impairing function, for example, GSIS. Bcl-XL overexpression improves $\beta$-cell survival, but impairs glucose oxidation and $\mathrm{GSIS}^{7}$ and the BH3-only protein BAD is also an important modulator of GSIS, ${ }^{41}$ suggesting that some members of the Bcl-2 family have 'day' and 'night' jobs in $\beta$-cells, affecting both cell survival and function. ${ }^{42}$ This is apparently not the case for Mcl-1 as neither Mcl-1 knockdown nor overexpression altered GSIS. These observations strongly suggest that the role of $\mathrm{Mcl}-1$ in $\beta$-cells is restricted to the control of apoptosis and underline $\mathrm{Mcl}-1$ as a promising target for the development of new strategies aiming to prevent $\beta$-cell apoptosis in diabetes.

\section{Materials and Methods}

Materials. The following chemicals were purchased from Sigma-Aldrich NV/SA (Bornem, Belgium) and used as indicated: MG-132 $(1 \mu \mathrm{M})$, tunicamycin $(10 \mu \mathrm{g} / \mathrm{ml})$, CPA $(20 \mu \mathrm{M})$, thapsigargin $(100 \mathrm{nM})$, salubrinal $(75 \mu \mathrm{M})$, forskolin $(10 \mu \mathrm{M})$, SP600125 $(10 \mu \mathrm{M})$, SB216763 $(5 \mu \mathrm{M}), \mathrm{BIO}(1 \mu \mathrm{M})$ and PD98059 $(30 \mu \mathrm{M})$ were dissolved in DMSO. L-NMMA (1 mM) was dissolved in distilled water. Oleate and palmitate (sodium salt; Sigma-Aldrich) were dissolved in $90 \%$ ethanol, heated to $60^{\circ} \mathrm{C}$ and diluted (final concentration $0.5 \mathrm{mM}$ ) in RPMI 1640 with $1 \% \mathrm{BSA}$ and $1 \%$ fetal calf serum (cFFA medium). ${ }^{13,26}$ The peptides JNK inhibitor L-TAT-JNKi and control peptide L-TAT (a kind gift from C Bonny and M Mathieu; XigenPharma, Lausanne, Switzerland) were dissolved in culture medium and used at $10 \mu \mathrm{M}$ as described previously. ${ }^{19}$ The following cytokine concentrations were used: recombinant human IL-1 $\beta$ (gift from CW Reinolds, National Cancer Institute, Bethesda, MD, USA) at $10 \mathrm{U} / \mathrm{ml}$ in INS-1E cells and $50 \mathrm{U} / \mathrm{ml}$ in primary cells; recombinant rat IFN- $\gamma$ (R\&D Systems, Abingdon, UK) at $100 \mathrm{U} / \mathrm{ml}(0.0072 \mu \mathrm{g} / \mathrm{ml})$ in INS- $1 \mathrm{E}$ cells and $500 \mathrm{U} / \mathrm{ml}(0.036 \mu \mathrm{g} / \mathrm{ml})$ in primary cells: ${ }^{10}$ and recombinant human TNF- $\alpha$ (R\&D Systems) at $1000 \mathrm{U} / \mathrm{ml}$ in INS-1E cells and primary cells. The selected concentrations of ER stressors, FFA and cytokines are based on previous dose-response studies from our group..$^{10,12,26}$

Cell culture. The rat insulinoma cell line INS-1E (kindly provided by Prof. Claes Wollheim, CMU, University of Geneva, Geneva, Switzerland) was maintained in the complete RPMI 1640 medium as described previously. ${ }^{10}$

Male Wistar rats (Charles River Laboratories, Brussels, Belgium) were housed and manipulated according to the guidelines of the Belgian Regulations for Animal Care; all experiments performed were approved by the local ethics committee. Rat islets were isolated by collagenase digestion followed by hand picking under a stereomicroscope. Islets were then dispersed and primary $\beta$-cells were purified by FACS using the auto-fluorescent properties of $\beta$-cells (FACSAria, BD Bioscience, San Jose, CA, USA) ${ }^{10}$ The preparations used in this study contained $90.1 \pm 3.8 \% \beta$-cells $(n=11)$. Dispersed islets or FACS-purified $\beta$-cells were pre-cultured in complete $\beta$-cell medium supplemented with $5 \%$ heatinactivated fetal bovine serum from 20 to $48 \mathrm{~h}$ for recovery. ${ }^{13}$ Experiments were then conducted in the medium without serum. ${ }^{10}$

Western blot analysis. Cells were washed once with cold PBS and directly lysed with Laemmli buffer. Lysates were then resolved by SDS-PAGE and transferred to a PVDF membrane. Immunoblot analyses were performed as described previously, ${ }^{13,18}$ using the following antibodies: polyclonal anti-rat Mcl-1 from Biovision (Gentaur, Brussels, Belgium); polyclonal anti-CHOP/GADD153, monoclonal anti- $\beta$-catenin (D-10) and polyclonal anti-Bax (P-19) from Santa Cruz Biotechnology Inc. (Santa Cruz, CA, USA); polyclonal anti-P-GSK-3 $\alpha, \beta$, polyclonal anti-GSK-3 $\beta$, polyclonal anti-P-ERK1,2, polyclonal anti-ERK1,2, polyclonal anti-PPERK, polyclonal anti-PERK, polyclonal anti-P-elF2 $\alpha$, polyclonal anti-CoxIV, 
polyclonal anti-BiP, polyclonal anticleaved caspase-3, polyclonal anti-Bcl-2 and polyclonal anti-Bcl-XL from Cell Signaling (Boston, MA, USA); polyclonal anti-Bak from BD Biosciences-Europe (Erembodegem, Belgium); and monoclonal anti- $\alpha$ tubulin and horseradish peroxidase-conjugated goat anti-rabbit or anti-mouse IgG from Sigma-Aldrich.

RNA interference. The following siRNAs were used in this study:

Mcl-1 siRNA no. 1: rat Mcl-1 ON-TARGETplus SMARTpool siRNA (Dharmacon RNAi Technologies, Thermo Fisher Scientific, Aalst, Belgium). The SMARTpool is a mixture of four different siRNA: no. 1, GUAAGGACGAAGCGGGACU; no. 2, GUAGAACAAAUCCGAGUUA; no. 3, GAAUUGUGGCUAACGAGAA; and no. 4, GAUCAGUUCUAGUGUAUAU.

Mcl-1 siRNA no. 2: rat Mcl-1 Silencer Select pre-designed siRNA: CGAG GACGAUGUUAAAUCU from Ambion (Applied Biosystems, Lennik, Belgium).

PERK siRNA no. 1: rat Eif2ak3 ON-TARGETplus SMARTpool siRNA (Dharmacon) consisting of: no. 1, CAGGAUACGUGUCCCGAUA; no. 2, GAACAGG AGUCACGCGCGA; no. 3, CCGUCAGGUCUCGGAAAA; and no. 4, AUACAGUA AUGGUGCGCUU.

PERK SiRNA no. 2: rat Eif2ak3 Silencer Select pre-designed siRNA: GUAUCCAUAUGACAACGGU from Ambion. Allstars Negative Control siRNA (Qiagen, Venlo, the Netherlands), which has little effect on $\beta$-cell gene expression and no effect on cell viability. ${ }^{20}$ siRNA transfection were conducted according to a protocol developed in our laboratory ${ }^{13,20}$ using DharmaFECT 1 (Thermo Fisher Scientific) with a final concentration of $30 \mathrm{nM}$ siRNA. The efficiency of transfection was $>90 \%{ }^{13,20}$ Cells were then cultured for a 48-h recovery period before being collected or treated as indicated.

Generation of recombinant adenoviruses and cell infection. Ad-LUC was purchased from Vector Biolabs (Philadelphia, PA, USA). The adenovirus encoding rat Mcl-1 was generated by Vector Biolabs using rat myeloid cell leukemia 1 complete cds (cDNA clone MGC: 93459; IMAGE: 7121699; GenBank: BC078835) inserted in the pExpress-1 vector backbone (purchased at ImaGenes GmbH, Berlin, Germany). INS-1E cells and FACS-purified $\beta$-cells were infected as described previously. ${ }^{43}$

Assessment of cell viability. The percentage of viable, apoptotic and necrotic cells was determined using the DNA-binding dyes propidium iodide $(5 \mu \mathrm{g} / \mathrm{ml})$ and $\mathrm{HO}\left(5 \mu \mathrm{g} / \mathrm{ml}\right.$; Sigma-Aldrich).$^{10}$ The cells were examined by inverted fluorescence microscopy (Axiovert 200, Carl Zeiss, Zaventem, Belgium). A minimum of 500 cells was counted in each experimental condition by two independent observers, one of them unaware of the sample identity. There was no difference in viability between non-treated cells (control (ctrl)), cells exposed to the ER stressors solvent DMSO $(0.005-0.1 \%)$ or cells incubated in the FFA medium (data not shown); thus, the ctrl data showed in viability figures are mean \pm S.E.M. of the different controls used in the experiments. The necrosis levels were low throughout the experiments and were not significantly changed between different experimental conditions in INS-1E cells $(1.32 \pm 0.22 \%$ : mean necrosis levels in all conditions) and FACS-purified primary $\beta$-cells $(2.03 \pm 0.34 \%$ : mean necrosis levels in all conditions). Apoptosis was confirmed by caspase-3 cleavage (described above in 'Western blot analysis') and Bax translocation (see below in 'Immunofluorescence').

mRNA extraction and quantitative RT-PCR. Poly $(A)+$ mRNA was isolated from dispersed islet cells using the Dynabeads mRNA DIRECT kit (Invitrogen, Paisley, UK) and reverse transcribed as described previously. ${ }^{10}$ Quantitative PCR was performed using the IQ SYBR Green Supermix (BIO-RAD, Nazareth Eke, Belgium) in an IQ5 instrument (BIO-RAD). Expression values were corrected for the housekeeping gene glyceraldehyde-3-phosphate dehydrogenase (GAPDH). Cytokines, FFAs or ER stressors treatments do not modify GAPDH expression in insulin-producing cells under the present experimental conditions. ${ }^{10,12,26}$ The primers used in this study were: rat $M c l-1: \mathrm{FW}-5^{\prime}$-CCTCCAG CCACCAACTACAT-3'; rev - 5'-CCACTTTCTTTCTGCCGTGTTA-3'; and rat GAPDH: Fw - 5'-AGTTCAACGGCACAGTCAAG-3'; rev - 5'-TACTCAGCACCAG CATCACC-3'.

Subcellular fractionation. One million INS-1E cells plated in a six-well plate were infected using Ad-LUC or Ad-Mcl-1. After $48 \mathrm{~h}$, cells were extracted using the PIERCE Mitochondria Isolation Kit for Cultured Cells (Thermo Fisher Scientific) according to the manufacturer's instructions.
Immunofluorescence. INS-1E cells grown on glass culture slides (BD Biosciences Europe, Erembodegem, Belgium) were fixed for $15 \mathrm{~min}$ in fresh $4 \%$ paraformaldehyde, rinsed in PBS and permeabilized for $5 \mathrm{~min}$ in PBS-Triton $\mathrm{X}-1000.1 \%$. Slides were then blocked using PBS-goat serum $5 \%$ and incubated overnight at $4^{\circ} \mathrm{C}$ in the presence of polyclonal rabbit anti-Bax (1/1000; Santa Cruz Biotechnology Inc.), monoclonal mouse anti-cytochrome $c$ or anti-ATP synthase $\beta$ (1/2000; BD Biosciences). For the proliferation assay using BrdU, INS-1E cells were incubated for $6 \mathrm{~h}$ in a $100 \mu \mathrm{M}$ BrdU solution before fixation. After PBS washing, DNA was denaturated by incubating cells in $\mathrm{HCl} 2 \mathrm{~N}$ for $30 \mathrm{~min}$. Acid solution was neutralized by washing twice in borate buffer $0.1 \mathrm{M}$. Slides were then blocked using PBS-goat serum $5 \%$ and incubated overnight at $4{ }^{\circ} \mathrm{C}$ in the presence of purified mouse anti-BrDU (1/500; BD Biosciences). Cells were then washed and further exposed for $1 \mathrm{~h}$ to appropriate Alexa Fluor 488- or 555-conjugated antibodies (1/1000; NV Invitrogen SA, Merelbeke, Belgium). After washing, cells were stained with $\mathrm{HO}$, mounted and photographed using fluorescence microscopy (Axio Imager, Carl Zeiss). A minimum of 600 cells was counted in each experimental condition by two independent observers, one of them unaware of the sample identity.

Insulin secretion measurements. INS-1E cells were plated at a density of 150000 cells per condition. At $48 \mathrm{~h}$ after infection or transfection, cells were incubated for $30 \mathrm{~min}$ in glucose-free INS-1E medium. Cells were washed in KRBH (Krebs-Ringer/bicarbonate-HEPES) buffer and pre-incubated for $30 \mathrm{~min}$ in glucose-free KRBH buffer $\left(20 \mathrm{mM} \mathrm{NaCl}, 3.5 \mathrm{mM} \mathrm{KCl}, 0.5 \mathrm{mM} \mathrm{NaH}_{2} \mathrm{PO}_{4}, 1.5 \mathrm{mM}\right.$ $\mathrm{CaCl}_{2}, 5 \mathrm{mM} \mathrm{NaHCO}_{3}, 10 \mathrm{mM}$ HEPES and $0.1 \% \mathrm{BSA}$ ). Cells were then incubated for $30 \mathrm{~min}$ in KRBH supplemented with $1.67 \mathrm{mM}$ glucose, $16.7 \mathrm{mM}$ glucose or $16.7 \mathrm{mM}$ glucose $+10 \mu \mathrm{M}$ forskolin. Insulin release was measured using the High Range Rat Insulin ELISA according to the manufacturer's instruction (Mercodia AB, Uppsalla, Sweden).

Statistical analyses. Data are presented as means \pm S.E.M. Comparisons were performed by two-tailed paired Student's $t$-test or by ANOVA, followed by $t$-tests with Bonferroni correction for multiple comparison. A $P$-value $\leqslant 0.05$ was considered statistically significant.

Conflict of interest. The authors declare no conflict of interest.

Acknowledgements. This work was supported by grants from the Juvenile Diabetes Research Foundation (JDRF) International (1-2008-536), Fonds National de la Recherche Scientifique (FNRS - FRSM) Belgium, the Communauté Française de Belgique - Actions de Recherche Concertées (ARC), the European Union (Integrated Projects EuroDia in the Framework Programme 6 [FP6] and Naimit in the FP7 of the European Community) and the Belgium Program on Interuniversity Poles of Attraction initiated by the Belgium State (IUAP P6/40). AK Cardozo is a Research Associate of the FNRS; F Allagnat is supported by the JDRF; F Moore is the recipient of a Post-Doctoral Fellowship from FNRS, Belgium; and JM Vanderwinden is a Research Director of the FNRS. We thank MA Neef, G Vandenbroeck, M Urbain, R Leeman, AM Musuaya, R Makhnas and S Mertens from the Laboratory of Experimental Medicine, ULB, for excellent technical support.

1. Cnop M, Welsh N, Jonas JC, Jorns A, Lenzen S, Eizirik DL. Mechanisms of pancreatic beta-cell death in type 1 and type 2 diabetes: many differences, few similarities. Diabetes 2005; 54 (Suppl 2): S97-107.

2. Youle RJ, Strasser A. The BCL-2 protein family: opposing activities that mediate cell death. Nat Rev Mol Cell Biol 2008; 9: 47-59.

3. Thomas HE, McKenzie MD, Angstetra E, Campbell PD, Kay TW. Beta cell apoptosis in diabetes. Apoptosis 2009; 14: 1389-1404.

4. Kroemer G, Galluzzi L, Brenner C. Mitochondrial membrane permeabilization in cell death. Physiol Rev 2007; 87: 99-163.

5. Carrington EM, McKenzie MD, Jansen E, Myers M, Fynch S, Kos C et al. Islet beta-cells deficient in $\mathrm{Bcl}-\mathrm{xL}$ develop but are abnormally sensitive to apoptotic stimuli. Diabetes 2009; 58: 2316-2323.

6. Rabinovitch A, Suarez-Pinzon W, Strynadka K, Ju Q, Edelstein D, Brownlee M et al. Transfection of human pancreatic islets with an anti-apoptotic gene ( $\mathrm{bcl}-2)$ protects betacells from cytokine-induced destruction. Diabetes 1999; 48: 1223-1229.

7. Zhou YP, Pena JC, Roe MW, Mittal A, Levisetti M, Baldwin AC et al. Overexpression of $\mathrm{Bcl}-\mathrm{x}(\mathrm{L})$ in beta-cells prevents cell death but impairs mitochondrial signal for insulin secretion. Am J Physiol Endocrinol Metab 2000; 278: E340-E351.

8. Yang-Yen HF. Mcl-1: a highly regulated cell death and survival controller. J Biomed Sci 2006; 13: 201-204. 
9. Yang T, Kozopas KM, Craig RW. The intracellular distribution and pattern of expression of Mcl-1 overlap with, but are not identical to, those of Bcl-2. J Cell Biol 1995; 128: 1173-1184.

10. Cardozo AK, Ortis F, Storling J, Feng YM, Rasschaert J, Tonnesen M et al. Cytokines downregulate the sarcoendoplasmic reticulum pump $\mathrm{Ca}^{2+}$ ATPase $2 \mathrm{~b}$ and deplete endoplasmic reticulum $\mathrm{Ca}^{2+}$, leading to induction of endoplasmic reticulum stress in pancreatic beta-cells. Diabetes 2005; 54: 452-461.

11. Boyce M, Bryant KF, Jousse $C$, Long K, Harding HP, Scheuner D et al. A selective inhibitor of elF2alpha dephosphorylation protects cells from ER stress. Science 2005; 307 935-939.

12. Kharroubi I, Ladriere L, Cardozo AK, Dogusan Z, Cnop M, Eizirik DL. Free fatty acids and cytokines induce pancreatic beta-cell apoptosis by different mechanisms: role of nuclea factor-kappaB and endoplasmic reticulum stress. Endocrinology 2004; 145: 5087-5096.

13. Cunha DA, Hekerman P, Ladriere L, Bazarra-Castro A, Ortis F, Wakeham MC et al. Initiation and execution of lipotoxic ER stress in pancreatic beta-cells. J Cell Sci 2008; 121 2308-2318.

14. Cunha DA, Ladriere L, Ortis F, Igoillo-Esteve M, Gurzov EN, Lupi R et al. Glucagon-like peptide-1 agonists protect pancreatic beta-cells from lipotoxic endoplasmic reticulum stress through upregulation of BiP and JunB. Diabetes 2009; 58: 2851-2862.

15. Bregenholt S, Moldrup A, Blume N, Karlsen AE, Nissen Friedrichsen B, Tornhave D et al. The long-acting glucagon-like peptide-1 analogue, liraglutide, inhibits beta-cell apoptosis in vitro. Biochem Biophys Res Commun 2005; 330: 577-584.

16. Inoshita S, Takeda K, Hatai T, Terada Y, Sano M, Hata J et al. Phosphorylation and inactivation of myeloid cell leukemia 1 by JNK in response to oxidative stress. J Biol Chem 2002; 277: 43730-43734

17. Cardozo AK, Ortis F, Storling J, Feng YM, Rasschaert J, Tonnesen M et al. Cytokines downregulate the sarcoendoplasmic reticulum pump $\mathrm{Ca}^{2+}$ ATPase $2 \mathrm{~b}$ and deplete endoplasmic reticulum $\mathrm{Ca}^{2+}$, leading to induction of endoplasmic reticulum stress in pancreatic beta-cells. Diabetes 2005; 54: 452-461.

18. Gurzov EN, Ortis F, Cunha DA, Gosset G, Li M, Cardozo AK et al. Signaling by IL-1beta+IFN-gamma and ER stress converge on DP5/Hrk activation: a novel mechanism for pancreatic beta-cell apoptosis. Cell Death Differ 2009; 16: 1539-1550.

19. Bonny C, Oberson A, Negri S, Sauser C, Schorderet DF. Cell-permeable peptide inhibitors of JNK: novel blockers of beta-cell death. Diabetes 2001; 50: 77-82.

20. Moore F, Colli ML, Cnop M, Esteve MI, Cardozo AK, Cunha DA et al. PTPN2, a candidate gene for type 1 diabetes, modulates interferon-gamma-induced pancreatic beta-cell apoptosis. Diabetes 2009; 58: 1283-1291.

21. Ortis F, Cardozo AK, Crispim D, Storling J, Mandrup-Poulsen T, Eizirik DL. Cytokine-induced proapoptotic gene expression in insulin-producing cells is related to rapid, sustained, and nonoscillatory nuclear factor-kappaB activation. Mol Endocrinol 2006; 20: 1867-1879.

22. Coghlan MP, Culbert AA, Cross DA, Corcoran SL, Yates JW, Pearce NJ et al. Selective small molecule inhibitors of glycogen synthase kinase-3 modulate glycogen metabolism and gene transcription. Chem Biol 2000; 7: 793-803.

23. Sato N, Meijer L, Skaltsounis L, Greengard P, Brivanlou AH. Maintenance of pluripotency in human and mouse embryonic stem cells through activation of Wnt signaling by a pharmacological GSK-3-specific inhibitor. Nat Med 2004; 10: 55-63.

24. Germain M, Milburn J, Duronio V. MCL-1 inhibits BAX in the absence of MCL-1/BAX Interaction. J Biol Chem 2008; 283: 6384-6392.

25. Matsushita K, Okita H, Suzuki A, Shimoda K, Fukuma M, Yamada T et al. Islet cell hyperplasia in transgenic mice overexpressing EAT/mcl-1, a bcl-2 related gene. Mol Cell Endocrinol 2003; 203: 105-116.

26. Cnop M, Ladriere L, Hekerman P, Ortis F, Cardozo AK, Dogusan Z et al. Selective inhibition of eukaryotic translation initiation factor 2 alpha dephosphorylation potentiates fatty acid-induced endoplasmic reticulum stress and causes pancreatic beta-cell dysfunction and apoptosis. J Biol Chem 2007; 282: 3989-3997.

27. Fritsch RM, Schneider G, Saur D, Scheibel M, Schmid RM. Translational repression of MCL-1 couples stress-induced elF2 alpha phosphorylation to mitochondrial apoptosis initiation. J Biol Chem 2007; 282: 22551-22562.

28. Snyder CM, Shroff EH, Liu J, Chandel NS. Nitric oxide induces cell death by regulating antiapoptotic BCL-2 family members. PLoS One 2009; 4: e7059.

29. Bonny C, Oberson A, Steinmann M, Schorderet DF, Nicod P, Waeber G. IB1 reduces cytokine-induced apoptosis of insulin-secreting cells. J Biol Chem 2000; 275: 16466-16472.

30. Rahmani M, Davis EM, Crabtree TR, Habibi JR, Nguyen TK, Dent $P$ et al. The kinase inhibitor sorafenib induces cell death through a process involving induction of endoplasmic reticulum stress. Mol Cell Biol 2007; 27: 5499-5513.

31. Maurer U, Charvet C, Wagman AS, Dejardin E, Green DR. Glycogen synthase kinase-3 regulates mitochondrial outer membrane permeabilization and apoptosis by destabilization of MCL-1. Mol Cell 2006; 21: 749-760.

32. Gurzov EN, Germano CM, Cunha DA, Ortis F, Vanderwinden JM, Marchetti $P$ et al. Puma activation contributes to pancreatic beta cell apoptosis induced by pro-inflammatory cytokines and endoplasmic reticulum stress. J Biol Chem 2010; 285: 19910-19920.

33. Zhai D, Jin C, Huang Z, Satterthwait AC, Reed JC. Differential regulation of Bax and Bak by anti-apoptotic Bcl-2 family proteins Bcl-B and Mcl-1. J Biol Chem 2008; 283: 9580-9586.

34. Roucou X, Montessuit S, Antonsson B, Martinou JC. Bax oligomerization in mitochondrial membranes requires tBid (caspase-8-cleaved Bid) and a mitochondrial protein. Biochem $J$ 2002; 368: 915-921.

35. McKenzie MD, Carrington EM, Kaufmann T, Strasser A, Huang DC, Kay TW et al. Proapoptotic BH3-only protein Bid is essential for death receptor-induced apoptosis of pancreatic beta-cells. Diabetes 2008; 57: 1284-1292.

36. Clohessy JG, Zhuang J, de Boer J, Gil-Gomez G, Brady HJ. Mcl-1 interacts with truncated Bid and inhibits its induction of cytochrome $c$ release and its role in receptor-mediated apoptosis. J Biol Chem 2006; 281: 5750-5759.

37. Chen L, Willis SN, Wei A, Smith BJ, Fletcher JI, Hinds MG et al. Differential targeting of prosurvival $\mathrm{Bcl}-2$ proteins by their $\mathrm{BH} 3$-only ligands allows complementary apoptotic function. Mol Cell 2005; 17: 393-403.

38. Akerfeldt MC, Howes J, Chan JY, Stevens VA, Boubenna N, McGuire HM et al. Cytokineinduced beta-cell death is independent of endoplasmic reticulum stress signaling. Diabetes 2008; 57: 3034-3044.

39. Huang CJ, Lin CY, Haataja L, Gurlo T, Butler AE, Rizza RA et al. High expression rates of human islet amyloid polypeptide induce endoplasmic reticulum stress mediated beta-cell apoptosis, a characteristic of humans with type 2 but not type 1 diabetes. Diabetes 2007; 56: 2016-2027.

40. Oyadomari S, Takeda K, Takiguchi M, Gotoh T, Matsumoto M, Wada I et al. Nitric oxideinduced apoptosis in pancreatic beta cells is mediated by the endoplasmic reticulum stress pathway. Proc Natl Acad Sci USA 2001; 98: 10845-10850.

41. Danial NN, Walensky LD, Zhang CY, Choi CS, Fisher JK, Molina AJ et al. Dual role of proapoptotic BAD in insulin secretion and beta cell survival. Nat Med 2008; 14: 144-153.

42. Hetz $\mathrm{C}$, Glimcher $\mathrm{L}$. The daily job of night killers: alternative roles of the $\mathrm{BCL}-2$ family in organelle physiology. Trends Cell Biol 2008; 18: 38-44.

43. Heimberg $\mathrm{H}$, Heremans $\mathrm{Y}$, Jobin $\mathrm{C}$, Leemans $\mathrm{R}$, Cardozo AK, Darville $\mathrm{M}$ et al. Inhibition of cytokine-induced NF-kappaB activation by adenovirus-mediated expression of a NF-kappaB super-repressor prevents beta-cell apoptosis. Diabetes 2001; 50: 2219-2224.

Supplementary Information accompanies the paper on Cell Death and Differentiation website (http://www.nature.com/cdd) 